\title{
NOVELTIES IN COSTA RICAN STELIS (ORCHIDACEAE: PLEUROTHALLIDINAE): TWO NEW SPECIES AND A NEW RECORD IN THE "DRACONTIA GROUP"
}

\author{
Adam P. Karremans ${ }^{1,2,3}$ \& Melissa Díaz-Morales ${ }^{1}$ \\ ${ }^{1}$ Jardín Botánico Lankester, Universidad de Costa Rica, P.O. Box 302-7050 Cartago, Costa Rica \\ ${ }^{2}$ Naturalis Biodiversity Center - Leiden University, The Netherlands \\ ${ }^{3}$ Author for correspondence: adam.karremans@ucr.ac.cr
}

\begin{abstract}
Stelis dies-natalis and Stelis aenigma, belonging to a group of mostly Middle American species alternatively placed in genus Dracontia, are described and illustrated based on living material. They were both found in oak forests at high elevations on diverse peaks of the Talamanca mountain range in Costa Rica. The first, S. dies-natalis, was found on Cerro Buena Vista and Cerro Urán, and is somewhat similar to S. hydra but can be distinguished by the relatively short inflorescence, the dark purple flowers with a yellow lip covered by dark purple warts, the apiculate apex of the petals and the lip with a shortly acuminate apicule. The second, $S$. aenigma, was initially believed to be a specimen of $S$. dies-natalis when it was collected on Cerro Utyum, but it can be easily distinguished by the few-flowered inflorescence that barely exceeds the leaf, the reddish flowers, the sigmoid lip and the cucullate, obtuse anther. Stelis platystylis, a species previously known from Mexico to Nicaragua is illustrated based on living material from Costa Rica.
\end{abstract}

Resumen. Stelis dies-natalis y Stelis aenigma, pertenecientes a un grupo de especies en su mayoría Centroamericanas colocadas alternativamente en el género Dracontia, son descritas e ilustradas basadas en material vivo. Ambas se encontraron en robledales de altura en diferentes picos de la Cordillera de Talamanca en Costa Rica. La primera, S. dies-natalis, se encontró en los Cerros Buena Vista y Urán, es similar a $S$. hydra pero se puede distinguir por la inflorescencia relativamente corta, las flores morado oscuro con un labelo amarillo cubierto por verrugas morado oscuro, los pétalos apiculados y el labelo con un apículo brevemente acuminado. La segunda, S. aenigma, que se pensaba inicialmente que se trataría de un espécimen de $S$. diesnatalis cuando se colectó en el Cerro Utyum, pero se puede distinguir fácilmente por las inflorescencias con pocas flores que apenas supera el tamaño de la hoja, las flores rojizas, el labelo sigmoideo y la antera obtusa y cuculada. Stelis platystylis, una especie previamente conocida de México a Nicaragua, es ilustraba basada en material vivo de Costa Rica.

Key words: Dracontia, Stelis, S. aenigma, S. dies-natalis, S. hydra, S. platystylis.

Introduction. Luer (1986) proposed Pleurothallis subgenus Dracontia Luer for a relatively small group of species mostly from Middle America. The group was transferred to a broad concept of Stelis Sw. by Pridgeon and Chase (2001) with support of DNA evidence (Pridgeon, Solano \& Chase 2001). Convinced that they required recognition as a distinct genus, Luer (2004) elevated Dracontia (Luer) Luer to generic level. Karremans (2011) suggested that Dracontia could be kept separate from Stelis arguing that the species formed a well recognizable natural group that could be segregated on morphological and genetic grounds. A broad DNA-based phylogenetic analysis by Karremans et al. (2012) confirmed that the species of Dracontia formed a highly supported monophyletic group, but also that there were imbedded in Stelis s.l. together with species placed in the genera Effusiella Luer, Elongatia (Luer) Luer, Mystacorchis Szlach. \& Marg., Salpistele Dressler and Unciferia (Luer) Luer. Dracontia cannot be recognized as currently defined and on its own, and is therefore considered part of a broad concept of Stelis (Karremans 2016).

Species of this particular group can be recognized by their successive, frequently undetermined inflorescences, fleshy flowers with long, thick, three-lobed, movable lips, convergent sepals forming a synsepal that is similar 
to the dorsal sepal, concave, obtuse, papillose petals, a triangular column that is apically dentate and much shorter than the lip, an incumbent, helm-like, large anther (exceeding the column), a ventral stigma covered by a bubble-like rostellum, and two flat caudicles (Karremans 2011, Karremans et al. 2012). They are found from Mexico to Panama, with a single species in the Antilles. The highest species diversity is found in Costa Rica and Panama. Taking the two described here into consideration, there are 25 species that can currently be ascribed to this group, twenty of them are known to grow in Costa Rica (Luer 1986, Karremans 2011, 2012, Karremans \& Smith 2012), a key for all species was provided by Karremans \& Bogarín (2013).

\section{Taxonomic treatment}

\section{Stelis dies-natalis Karremans \& M.Díaz, sp. nov.}

TYPE: Costa Rica. San José: Pérez Zeledón, Cerro de la Muerte (Cerro Buena Vista), sobre sendero hacia antenas del ICE, 9 ${ }^{\circ} 40^{\prime} 52.10^{\prime}$ 'N, 8351'20.11' 'W, $2715 \mathrm{~m}$, bosque montano de robledales, 26 mayo 2015. M. Díaz 234, J. Alomía, N. Davin \& A. P. Karremans (holotype: JBL-spirit!; Fig. 1, 2).

Stelis dies-natalis is somewhat similar to Stelis hydra (Karremans \& C.M. Sm.) Karremans but can be distinguished by the short inflorescence, with the first flower barely reaching the leaf apex (vs. inflorescence far exceeding the leaf), flowers dark purple (vs. reddish purple) with a yellow lip covered by dark purple warts (vs. reddish-orange), the apex of the petals with a small apicule (vs. not apiculate) and the lip with a shortly acuminate apicule (vs. acute apex, without apicule).

Plant epiphytic, caespitose, erect, up to $26 \mathrm{~cm}$ tall. Roots basal, filiform, flexuosus, slender, ca. $1 \mathrm{~mm}$ in diameter. Ramicauls terete, slender, $1.8-15.5 \mathrm{~cm}$ long, 1-2 $\mathrm{mm}$ in diameter, enclosed by a thin, papyraceus, tubular, truncate sheath on the middle third of the ramicaul, and with two basal sheaths. Leaves suberect, coriaceous, sessile, elliptic, acute, emarginate, 3.9-10.2 $\times 0.9-2.9 \mathrm{~cm}$. Inflorescence successive, racemose, secund, apical, from a 4-13 mm long, triangular, prostrate spathe, peduncle $6.3-7.5 \mathrm{~cm}$ long, enclosed in the middle by a tubular sheet, $5 \mathrm{~mm}$ long, rachis $2.1-5.1 \mathrm{~cm}$ long, barely exceeding the leaf apex at anthesis, getting longer over time. Floral bracts short, hyaline, acute, 4-5.5 mm long. Pedicel cylindrical, 5.5-8.5 mm long, ovary clavate, $6 \mathrm{~mm}$ long. Flowers five, dark purple with a yellow lip profusely stained with dark purple on the warts. Dorsal sepal hirsute, involute, narrowly ovate to lanceolate, obtuse, concave, $13.8-15.0 \times 3.8-4.1 \mathrm{~mm}$, three-veined, dark purple. Lateral sepals hirsute, involute, connate to near the apex into an ovate to elliptic, concave synsepal, acute, bifid, 15.6-16.2 × 4.6-5.2 mm, 4-veined, dark purple suffused with white in the base. Petals concave, embracing the column, obovate, papillose externally, acute, with the apex involute making the petal look obtuse in lateral view, $4.0-5.3 \times 2.6-3.0 \mathrm{~mm}$, three-veined, yellowish white covered with purple papillae on the upper half and along the veins. Lip twisted downward, fleshy, three-lobed, $6.5-7.0 \times 2.0-2.3 \mathrm{~mm}$, the midlobe thick, ligulate, acute, apiculate, rugoseverrucose, yellow covered with dark purple warts, the lateral lobes basal, suborbicular, erect, hyaline-white, base of the lip hinged to the tip of the column-foot. Column semiterete, conical, 2.8-3.1 mm long, with a short, thick, straight, white column-foot. Anther cap conical, acute, rostrate, two-celled, ca. $1.2 \times 0.6 \mathrm{~mm}$. Pollinia two, whale tail-like, narrowly ovate-pyriform, $0.7 \mathrm{~mm}$ long, with two flat caudicles.

Additional material studied: Costa Rica. San José: Pérez Zeledón, P. I. La Amistad, Cordillera de Talamanca, sendero Herradura, que sube a fila Urán 9³1'47'N, 83³5'30'W, 2600-2808 m, 6 April 1995. R. Aguilar 3911, O. Garrote (CR!; CR-INB!).

Distribution and ECOlogy: The species is currently known from two localities, the peaks of Urán and Cerro Buena Vista on the north end of the Talamanca range, growing in montane oak forest, at an elevation of about $2700 \mathrm{~m}$. (Fig. 3). It has been recorded to flower in April and May.

Etymology: From the Latin dies natalis (birthday, anniversary), commemorating Carl Luer's 95th birthday.

Among the species belonging to the Dracontia group, Stelis dies-natalis is recognised by the relatively large plants with short, successive inflorescences, born from a small bract, the apiculate petals, the short, thick, conspicuously apiculate lip that is yellow with dark purple warts. It is somewhat similar to Stelis hydra but can be distinguished especially by the short in- 


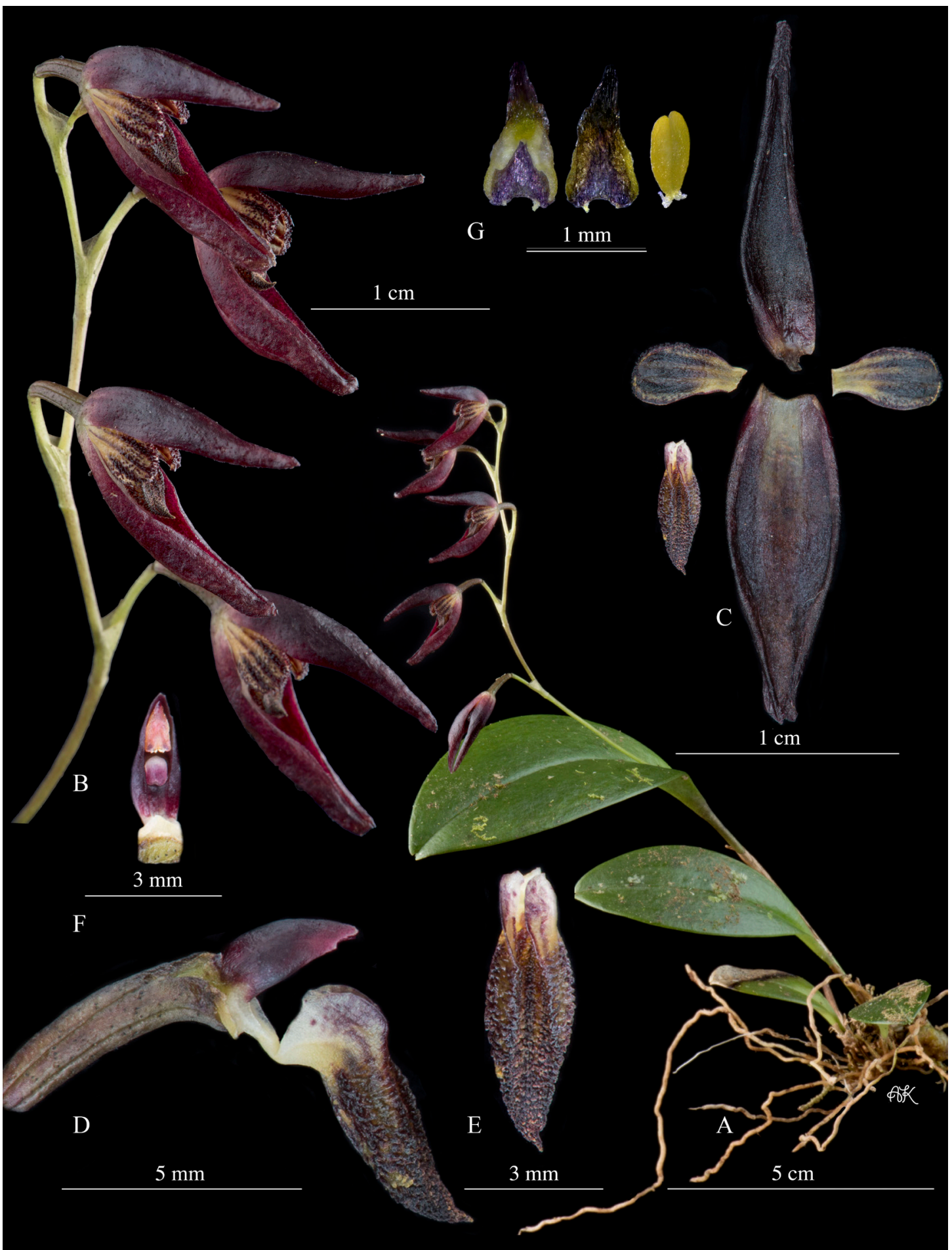

FIgure 1. Lankester Composite Dissection Plate (LCDP) of S. dies-natalis. A. Habit. B. Inflorescence. C. Dissected perianth. D. Column and lip in lateral view. E. Lip. F. Column in ventral view. G. Pollinia and anther cap. Photographs by A. Karremans and M. Díaz-Morales based on the plant that served as type (JBL-Spirit). 


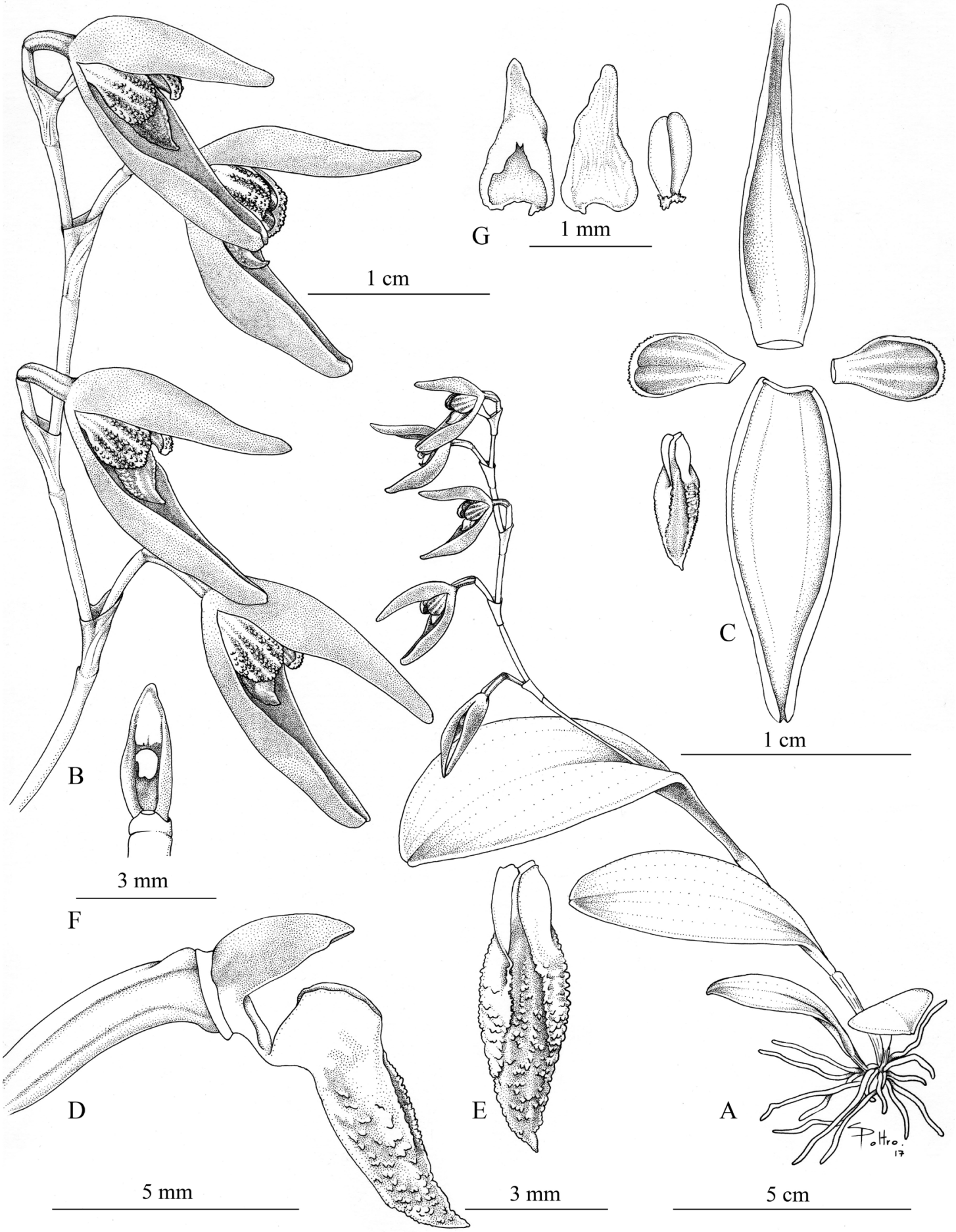

FiguRE 2. Stelis dies-natalis. A. Habit. B. Inflorescence. C. Dissected perianth. D. Column and lip in lateral view. E. Lip. F. Column in ventral view. G. Pollinia and anther cap. Drawing by Sara Díaz Poltronieri based on the plant that served as type (JBL-Spirit). 


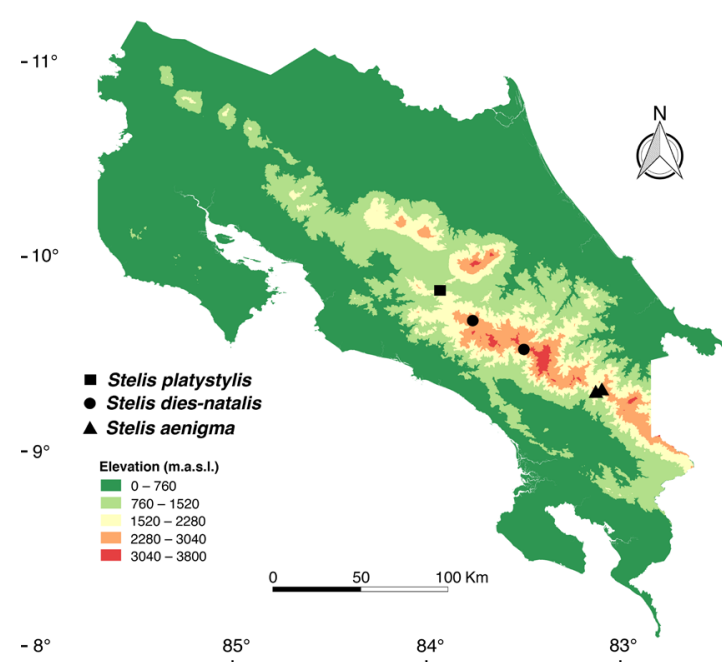

FIgURE 3. Distribution map of Stelis dies-natalis, S. aenigma and $S$. platystylis in Costa Rica.

florescence bearing dark purple flowers, with a yellow lip covered by dark purple warts, the apex of the petals apiculate and the lip with a shortly acuminate apicule.

\section{Stelis aenigma Karremans \& M.Díaz, sp. nov.}

TYPE: Costa Rica. Puntarenas: Buenos Aires, Buenos Aires, camino a Cerros Utyum, 9 ${ }^{\circ} 19^{\prime} 22.54$ 'N 83¹1'30.71" W, $2748 \mathrm{~m}$, bosque pluvial montano, epífita en bosque secundario, 19 de enero 2017, A. P. Karremans 8046, D. Bogarin, M. Cedeño, I. Chinchilla, M. Díaz, E. Kaes, P. Lehmann \& O. Zúñiga (holotype: JBL-spirit!; Figs. 4, 5).

Stelis aenigma is somewhat similar to Stelis diesnatalis but can be easily distinguished by the simultaneously few-flowered inflorescence (vs. successive, five or more flowers), the reddish (vs. dark purple) flowers, the sigmoid lip (vs. straight) and the cucullate, obtuse anther (vs. conical, acute).

Plant epiphytic, caespitose, erect, up to $18 \mathrm{~cm}$ tall. Roots basal, filiform, flexuosus, slender, ca. $1 \mathrm{~mm}$ in diameter. Ramicauls terete, slender, 8.0-8.7 cm long, $1-2 \mathrm{~mm}$ in diameter, enclosed by a thin, papyraceus, tubular, truncate sheath extending in the middle of the ramicaul, and with two basal sheaths. Leaves erect, coriaceous, sessile, elliptic, obtuse, emarginate, 6.8-8.4 $\times 2.6-3.0 \mathrm{~cm}$. Inflorescence simultaneously few flowered, racemose, secund, apical, from a $11 \mathrm{~mm}$ long, triangular, prostrate spathe, peduncle $6.7 \mathrm{~cm}$ long, en- closed in the middle by a tubular sheet, $10 \mathrm{~mm}$ long, rachis $1.5 \mathrm{~cm}$ long, apparently determinate. Floral bracts short, hyaline, acute, 5-6 mm long. Pedicel cylindrical, 7-8 mm long, ovary clavate, $4 \mathrm{~mm}$ long. Flowers one to three, reddish purple with a yellow lip, sometimes stained with red. Dorsal sepal involute, fine-hirsute on the margins, especially near the apex, narrowly ovate, obtuse, concave, 14.1-15.5 × 3.0-3.5 mm, three-veined, reddish purple suffused with white in the base. Lateral sepals involute, hirsute on the margins, especially near the apex, connate to near the apex into an ovate, concave synsepal, acute, emarginate, 14.0$15.2-\times 4.5-4.7 \mathrm{~mm}$, four-veined, reddish purple suffused with white in the base. Petals concave, embracing the column, obovate, papillose externally, acute, with the apex involute making the petal look obtuse in lateral view, 4.2-5.0 $\times 2.1-2.6 \mathrm{~mm}$, three-veined, yellowish white covered with purple papillae on the upper half and along the veins. Lip thick, ligulate, acute, with a fold at the apical third that makes the apex bend upward, $6.2-6.8 \times 1.8-2.0 \mathrm{~mm}$, rugose-verrucose, with erect margins near the base, base of the lip hinged to the tip of the column-foot, yellow suffused with purple on the basal margins and the lobes. Column semiterete, conical, 2.8-3.5 mm long, with a short, thick, slightly incurved column foot. Anther cap cucullate, obtuse, two-celled, ca. $0.9 \times 0.6 \mathrm{~mm}$. Pollinia two, whale taillike, narrowly ovate-pyriform, $0.5 \mathrm{~mm}$ long, with two flat caudicles.

Other ReCords: Costa Rica. Puntarenas: Buenos Aires, Buenos Aires, close to the continental divide, Cerro Arbolado, 9 ${ }^{\circ} 19^{\prime} 3.23^{\prime \prime} \mathrm{N} \quad 83^{\circ} 13^{\prime} 16.58^{\prime \prime} \mathrm{W}, 2435 \mathrm{~m}$. Photographed by Eberhard Kaes, the 5th of May 2014 (Fig. 6).

Distribution AND ECOLOgY: The only known specimens were found close to the continental divide between Cerro Arbolado and Cerro Utyum, southern Talamanca range, in Costa Rica. The species is found growing in montane oak forests between 2435 and 2748 m elevation (Fig. 3). It flowered in cultivation in April and in May in the field.

Eтymology: From the Latin aenigma (enigma, riddle), reflecting the unexpected nature of the discovery of this species which the authors initially believed would be a specimen of Stelis dies-natalis. 


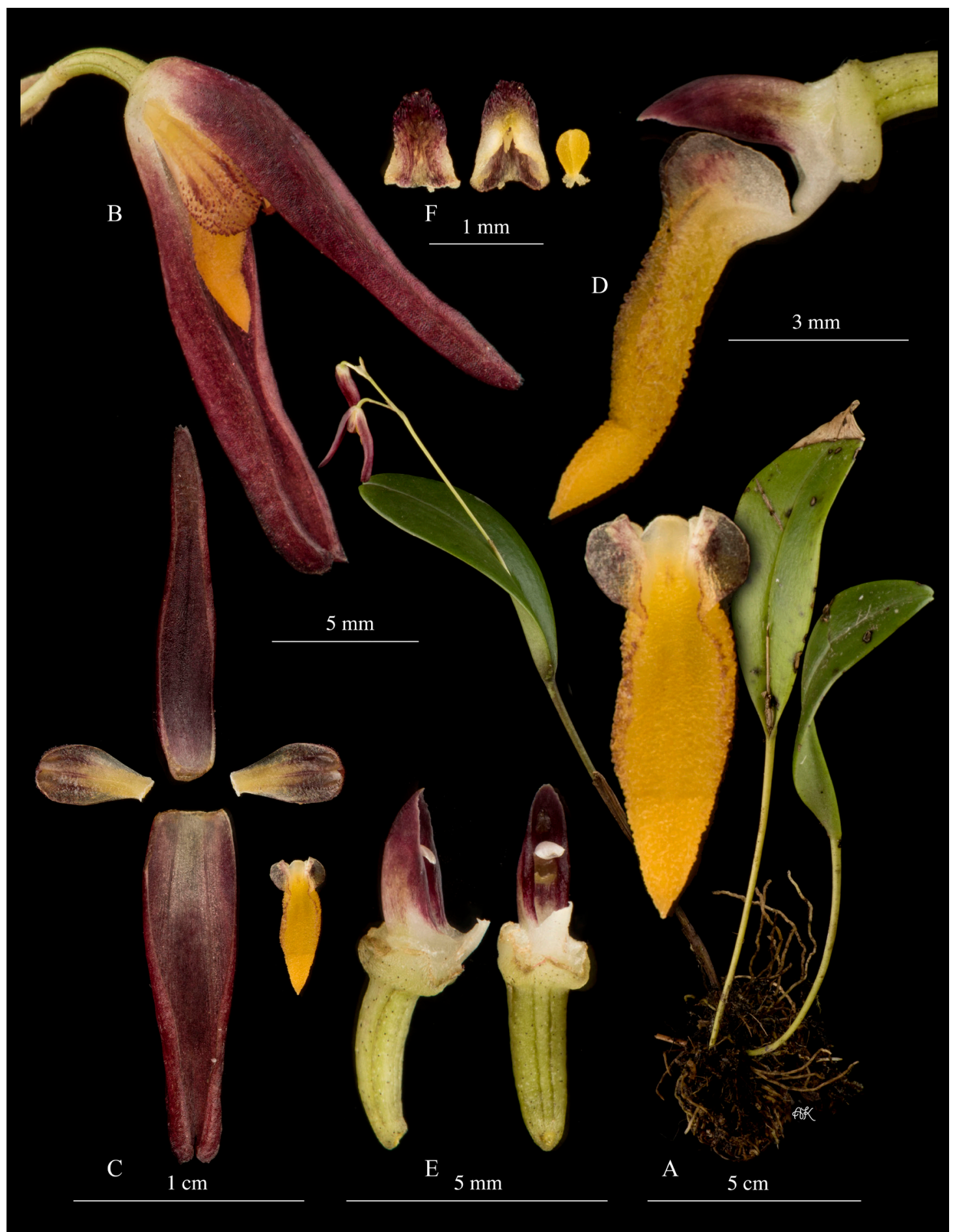

Figure 4. Lankester Composite Dissection Plate (LCDP) of S. aenigma. A. Habit. B. Flower. C. Dissected perianth. D. Column and lip in lateral view. E. Lip. F. Column in lateral and ventral view. G. Pollinia and anther cap. Photographs by A. Karremans based on the plant that served as type (JBL-Spirit). 


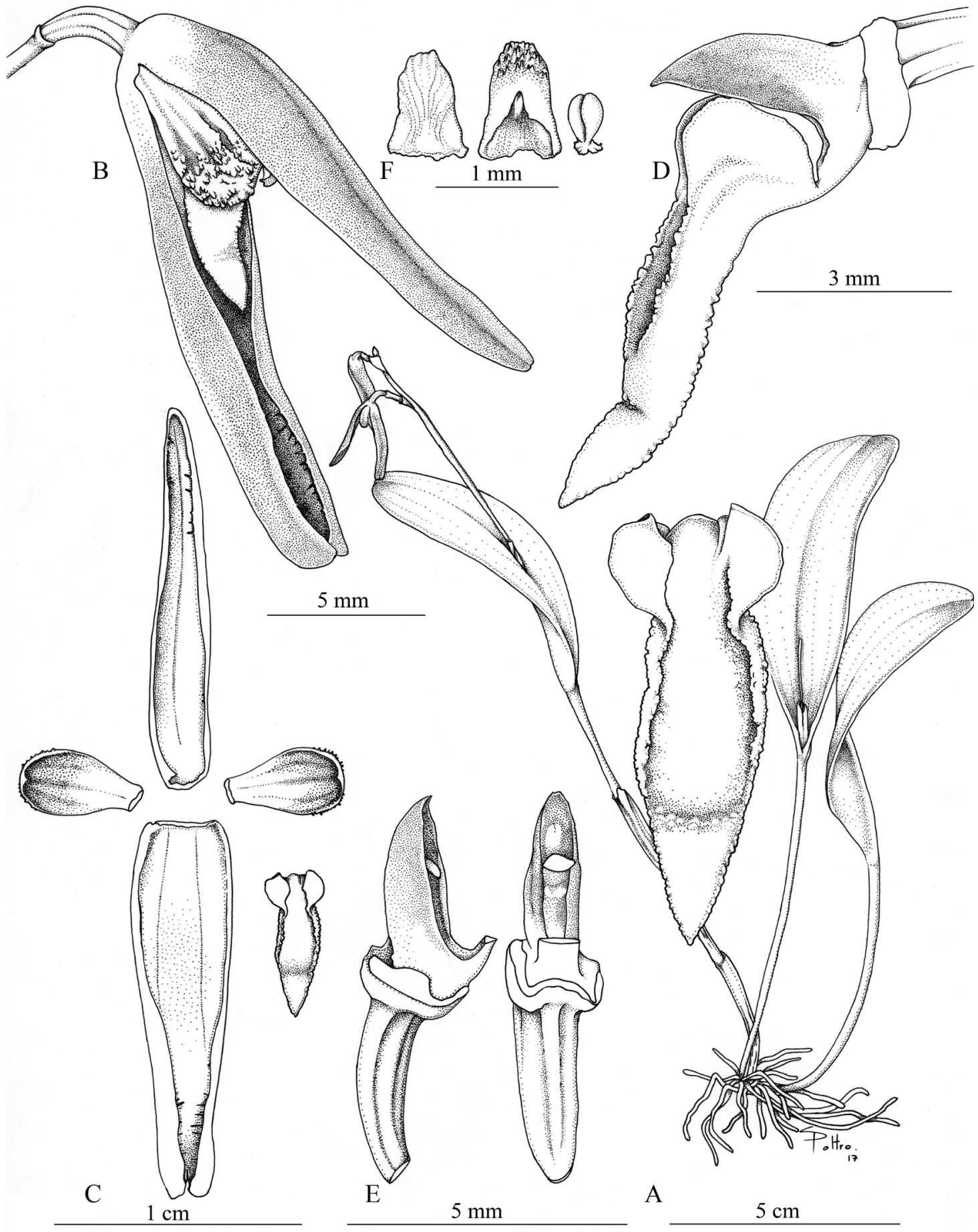

Figure 5. Stelis aenigma. A. Habit. B. Flower. C. Dissected perianth. D. Column and lip in lateral view. E. Lip. F. Column in lateral and ventral view. G. Pollinia and anther cap. Drawing by Sara Díaz Poltronieri based on the plant that served as type (JBL-Spirit). 


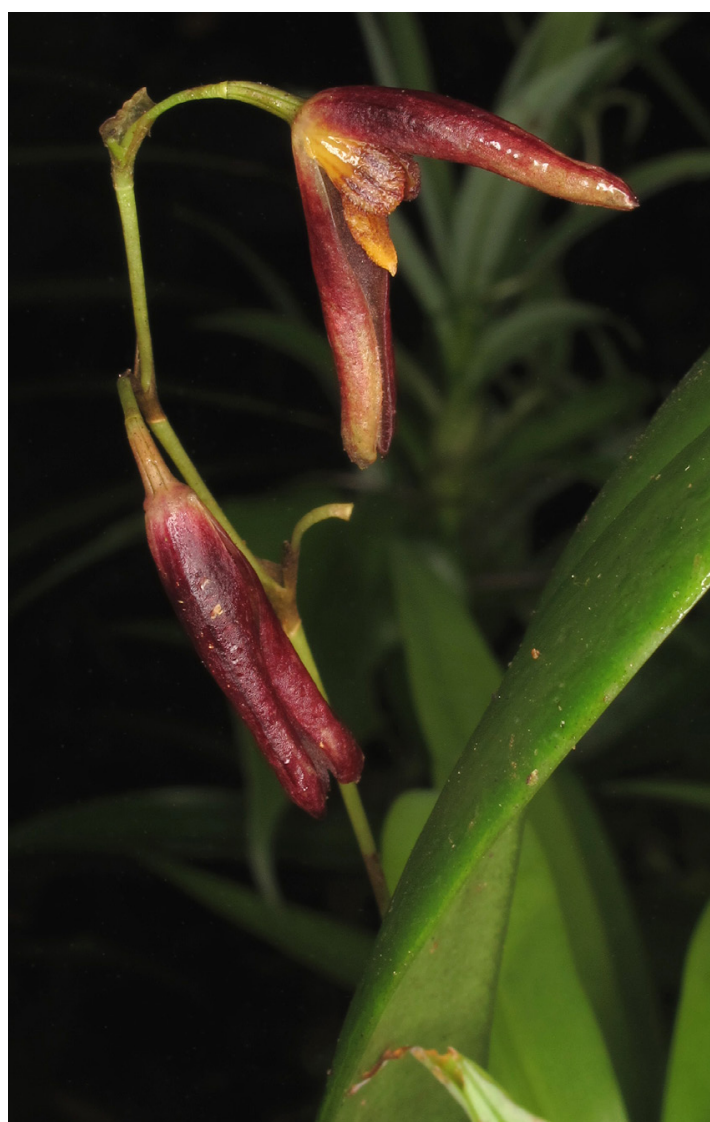

FIgURE 6. Stelis aenigma photographed in situ on Cerro

Arbolado. Photograph by E. Kaes.

When the plant that served as type of Stelis aenig$m a$ was found the authors believed it would be a specimen of S. dies-natalis; upon flowering it was clear that it was not. It can be easily distinguished from the latter by the simultaneously few-flowered inflorescence (vs. successive, five-plus flowers), the reddish (vs. dark purple) flowers, the sigmoid lip (vs. straight) and the cucullate, obtuse anther (vs. conical, acute). Among the species of Dracontia it is recognised by the simultaneously few-flowered inflorescence, the long, narrow sepals and yellow, sigmoid lip.

Stelis platystylis (Schltr.) Solano \& Soto Arenas, Icon. Orchid. 10: t. 1097. 2008.

Bas.: Pleurothallis platystylis Schltr., Repert. Spec. Nov. Regni Veg. 10: 395. 1912.

Syn.: Anathallis platystylis (Schltr.) Pridgeon \&

M.W.Chase, Lindleyana 16: 250. 2001. Specklinia platystylis (Schltr.) Luer, Monogr. Syst. Bot. Missouri Bot. Gard. 95: 263. 2004. Effusiella platystylis (Schltr.) Luer, Monogr. Syst. Bot. Missouri Bot. Gard. 112: 107. 2007.

TYPE: Guatemala: epiphytisch auf der Höhe zwischen Tactic und Cobán, ca. 2000 m, blühend im Dec 1906, H. von Türckheim II 1600 [holotype, B, destroyed; illustration of type, AMES-23667, selected as lectotype by Luer (2000)].

Distribution And eCOlogy: This species is apparently common in Mexico and Guatemala, and less frequent in Honduras, El Salvador, and Nicaragua. In Costa Rica, the single known specimen of this species was found at $1854 \mathrm{~m}$ in elevation close to Tablón, south of San José. It flowered in cultivation in January.

EтYMology: From the Greek platystylos, a broad style, in reference to the conspicuous anther cap that protrudes past the column apex.

Costa Rican material studied: San José: Desamparados, San Miguel, entre Tablón y Copalchí, 2 km oeste de Tablón, 950’07.10" N 8401'37.20" W, 1854 m, epífitas en bosque secundario y árboles de potreros en bosque muy húmedo montano bajo, 2 octubre 2008, D. Bogarín 5193, R.L. Dressler, R. Gómez, F. Pupulin, \& R. Trejos (JBL-Spirit!; Figs. $7,8)$.

This species has wandered in different genera without being clearly placed amongst its closest relatives. Pridgeon and Chase (2001) believed it to be an Anathallis Barb.Rodr. However, Luer (2000) treated it within Pleurothallis subgen. Effusia Luer, which he latter recognized as a distinct genus under the name Effusiella Luer. Karremans (2011) believed that the obtuse petals, three-lobed lip, helm-shaped anther cap that protrudes beyond the tip of the column, among other features, were suggestive of a Dracontia affinity. Such an affinity was later confirmed with DNA data (Karremans et al. 2012). The species' placement within a broad sense Stelis was not news, as the both Dracontia and Effusiella have been mostly considered synonyms of Stelis, however we can now also point at Stelis cobanensis (Schltr.) Pridgeon \& M.W. Chase and S. multirostris (Rchb. f.) Pridgeon \& M.W. Chase as being its closest relatives. 


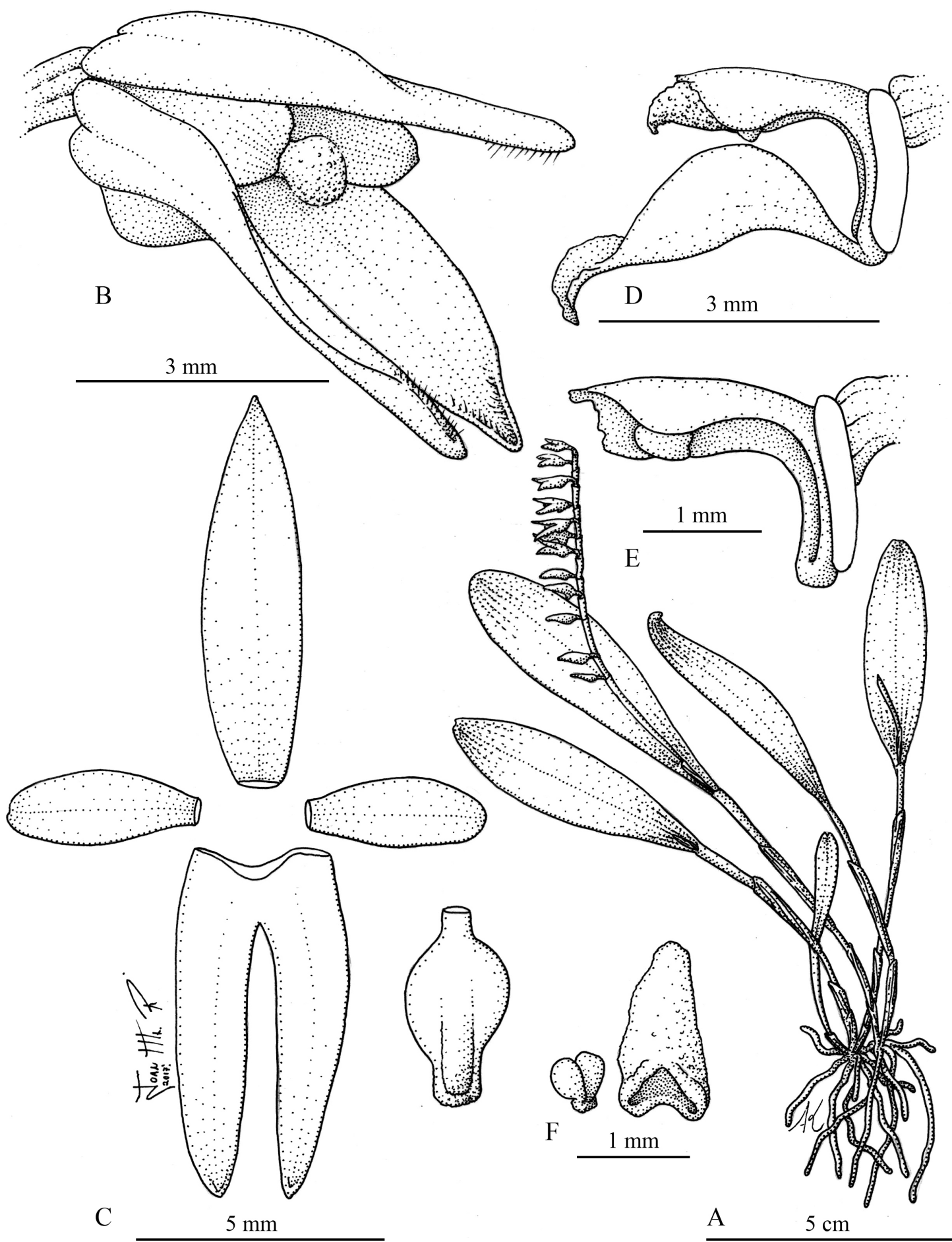

FiguRE 7. Stelis platystylis. A. Habit. B. Flower. C. Dissected perianth. D. Column and lip in lateral view. E. Column in lateral view. F. Pollinia and anther cap. Drawing by A. Karremans and J. Ramírez based on Bogarín 5193 (JBL-Spirit). 


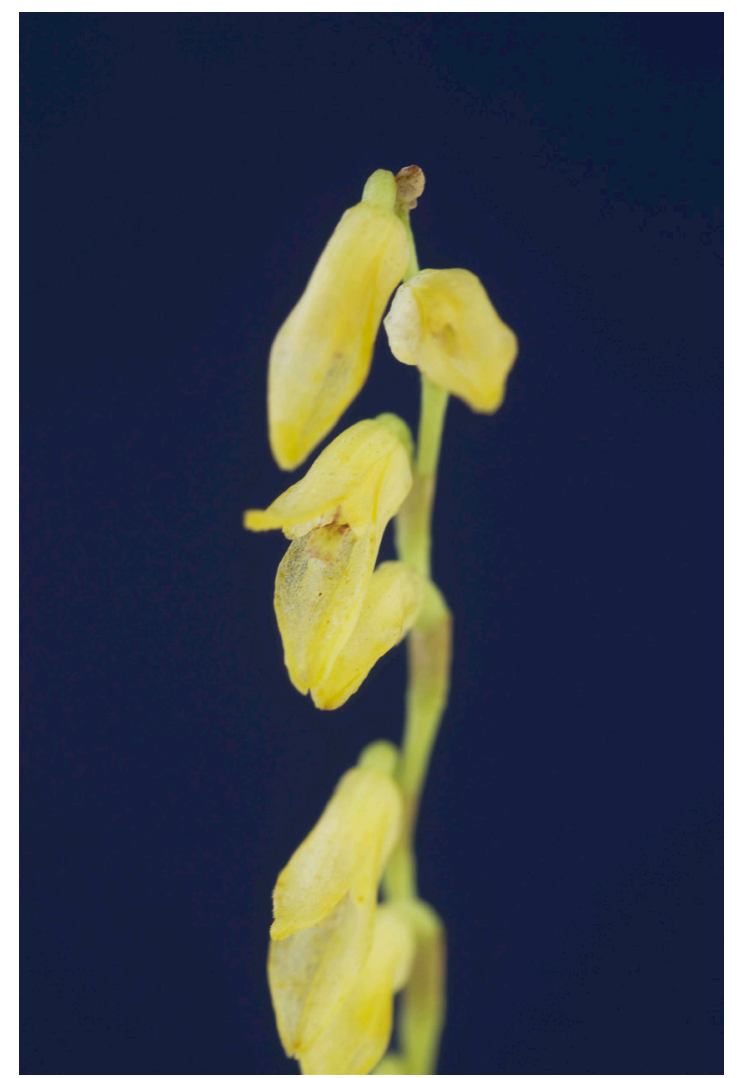

FIGURE 8. Inflorescence of $S$. platystylis with an open flower. Photograph by A. Karremans based on Bogarin 5193 (JBL-Spirit).

AcKnOwledgements. This manuscript was prepared as part of a dedicatory issue commemorating the 95th birthday of Carl Luer, who's extensive work on the Pleurothallidinae is the basis for most current studies in the subtribe, including the present. Joan Ramírez and Sara Díaz Poltronieri are thanked for their help in the illustration of these species. Eberhard Kaes is thanked for sharing their photographs of these species. We are also thankful to the Costa Rican Ministry of Environment and Energy (MINAE) and its National System of Conservation Areas (SINAC) for the scientific permits.

\section{LiTERATURE CITED}

Karremans, A. P. (2011). Dracontia, the little-known dragon orchids. Orchids, 80(9), 560-566.

Karremans, A. P. (2012). Illustrations and studies in Neotropical Orchidaceae. On the identity of Dracontia pachyglossa and D. ramonensis with a new species, $D$. lueriana (Pleurothallidinae). Annalen des Naturhistorischen Museums in Wien, B, 113, 119-132.

Karremans, A. P. (2016). Genera Pleurothallidinarum: an updated phylogenetic overview of Pleurothallidinae. Lankesteriana, 16(2), 219-241.

Karremans, A. P. \& Bogarín, D. B. (2013). Three new species of Dracontia (Pleurothallidinae, Orchidaceae) from Costa Rica. Systematic Botany, 38(2), 307-315.

Karremans, A. P. \& Smith, C. M. (2012). A note on genus Dracontia (Orchidaceae: Pleurothallidinae), with a new species. Harvard Papers in Botany, 17(1), 13-17.

Karremans, A. P., Bakker, F. T., Pupulin, F., Solano-Gómez, R. \& Smulders, M. J. M. (2012). Phylogenetics of Stelis and closely related genera (Orchidaceae: Pleurothallidinae). Plant Systematics and Evolution, doi: 10.1007/ s00606-012-0712-7.

Luer, C. A. (1986). Systematics of the genus Pleurothallis (Orchidaceae). Monographs in Systematic Botany from the Missouri Botanical Garden, 20, 1-108.

Luer, C. A. (2000). Icones Pleurothallidinarum. XX. Systematics of Jostia, Andinia, Barbosella, Barbrodia, Pleurothallis subgen. Antilla, subgen. Effusia, subgen. Restrepioidia. Addenda to Lepanthes, Masdevallia, Platystele, Pleurothallis, Restrepiopsis, Scaphosepalum, and Teagueia. Monographs in Systematic Botany from the Missouri Botanical Garden, 79, 1-140.

Luer, C. A. (2004). Icones Pleurothallidinarum XXVI. Pleurothallis subgenus Acianthera and three allied subgenera. A second century of new species of Stelis of Ecuador. Epibator, Ophidion, Zootrophion. Monographs in Systematic Botany from the Missouri Botanical Garden, 95, 1-265.

Pridgeon, A. M. \& Chase, M. W. (2001). A phylogenetic reclassification of Pleurothallidinae (Orchidaceae). Lindleyana, 16, 235-271.

Pridgeon, A.M., Solano, R. \& Chase, M.W. (2001). Phylogenetic relationships in Pleurothallidinae (Orchidaceae): combined evidence from nuclear and plastid DNA sequences. American Journal of Botany, 88, 2286-2308. 